\title{
Socio-economic drivers and non-indigenous freshwater crayfish species in Europe
}

\author{
Costas Perdikaris $^{(1)}$, Pavel Kozák ${ }^{(2)}$, Antonín Kouba ${ }^{(2)}$, \\ Evangelos Konstantinidis ${ }^{(3)}$, Ioannis Paschos ${ }^{(1)}$ \\ Received June 30, 2011 \\ Revised September 27, 2011 \\ Accepted October 11, 2011
}

\section{ABSTRACT}

Key-words: biodiversity, demographic pressures, economic growth, metabolic rifts, crayfish freshwater

\begin{abstract}
Non-indigenous freshwater crayfish species (NICS) outnumber the indigenous ones in many European countries, representing a major threat to biodiversity via the spread of crayfish 'plague' and aggressive invasion and antagonism performance. Although the biological basis of this situation is well studied, the possible role of social, economic and demographic factors on this situation has been ignored. In an attempt to explore such relationships, we suggest that human population density and economic growth (measured as gross domestic product (GDP) per capita) are positively related to the increased number of NICS in the EU area. Moreover, this pattern is evident in countries with higher overall footprint (i.e. the human demand of biologically productive land and sea in global hectares required to provide resources and services on waste assimilation) compared to biocapacity. Within the above context, actions are urgently needed to restore/balance existing and projected metabolic rifts (i.e. ruptures in the normal metabolic processes in natural systems) created by the presence of NICS.
\end{abstract}

\section{RÉSUMÉ}

\section{Facteurs socio-économiques et espèces non indigènes d'écrevisses d'eau douce en Europe}

\begin{abstract}
Mots-clés : biodiversité, pressions démographiques, croissance économique, clivages écologiques, écrevisses d'eau douce
\end{abstract}

(1) Freshwater Aquaculture Laboratory, Department of Aquaculture \& Fisheries, Technological Educational Institute of Epirus, Irinis \& Filias 1, 46100 Igoumenitsa, Greece, cperdik74@yahoo.gr

(2) South Bohemian Research Center of Aquaculture and Biodiversity of Hydrocenoses and Research Institute of Fish Culture and Hydrobiology, Faculty of Fisheries and Protection of Waters, University of South Bohemia in České Budějovice, Zátiši 728/II, 38925 Vod any, Czech Republic

(3) Department of Fisheries, Region of Epirus, 46100 Igoumenitsa, Greece 
(i.e. la demande humaine de terres biologiquement productives et de mer en hectares globaux nécessaires pour fournir des ressources et des services pour l'assimilation des déchets) par rapport à la biocapacité. Dans le contexte ci-dessus, des actions d'urgence sont nécessaires pour restaurer / gérer les ruptures métaboliques existantes et prévues (i.e. les ruptures dans les processus métaboliques normaux dans les systèmes naturels) créées par la présence de NICS.

\section{INTRODUCTION}

Social forces are widely accepted as the dominant factor shaping natural environment, especially after the last industrial revolution in the 19th century (Foster, 1999a), or even earlier during the transition from the feudalist to the capitalist era (Moore, 2000). Material exchanges at cellular and organism level, as well as in the intensive agriculture were initially described as metabolism by the German chemist Justus von Liebig during 1850s. Agricultural activities led to soil depletion through the transportation of nutrients from the country to the cities where they accumulated as wastes. Carl Marx being aware of human dependence on nature employed in his critique of political economy the concept of metabolism to refer to the complex, dynamic interchange between humans and nature. However, under Marx's theory, humans are unable to maintain sustainable conditions of production (e.g. nutrients recycling) because such conditions are an obstacle to the pursuit of profit through the increase of operations. Therefore, metabolic rifts (i.e. ruptures of metabolic processes in the natural ecosystems) are created leading to ecological degradation (Foster, 2000).

'Modernization' processes such as economic growth, industrialization and urbanization, along with demographic pressures are considered as critical to environmental issues such as biodiversity, climate change and ecological health of the natural environment (Czech et al., 2000; Clausen and York, 2008). This is particularly true for aquatic environment where degradation is continually documented (for instance, $38 \%$ of the native freshwater fish species in Europe are currently threatened; Kottelat and Freyhof, 2007), but in a rather isolated manner from the social and economic environment. Only recently, the influences of economic growth have started to be examined against the possibilities of further widening existing metabolic rifts in the aquatic environment, primarily on a macro-scale (Clausen and Clark, 2005; Clausen and York, 2008; Perdikaris and Paschos, 2011). Therefore, focused studies on particular species/taxa, production processes or sectors would shed more light on the specific coevolving interactions between man and the natural environment (e.g. the description of metabolic rifts created in Mediterranean bluefin tuna fishery in Sicily; Longo, 2010).

Freshwater crayfish have an over time importance to local European societies both as utilitarian (food) and cultural/traditional items since the ancient times (Swahn, 2004; Koutrakis et al., 2009; Gherardi, 2011). The populations of the five European indigenous crayfish species (ICS) [noble crayfish (Astacus astacus (Linnaeus, 1758), narrow-clawed crayfish Astacus leptodactylus Eschscholtz, 1823, thick-clawed crayfish Astacus pachypus Rathke, 1837, stone crayfish Austropotamobius torrentium (Schrank, 1803) and white-clawed crayfish Austropotamobius pallipes (Lereboullet, 1858)] once abundant, were seriously devastated by the 'crayfish plague' which was brought by asymptomatic crayfish species initially imported from North America during the late 19th century (Alderman, 1996; Diéguez-Uribeondo, 2006). Moreover, pollution and eutrophication, overharvest, agro-chemical runoffs, alteration/destruction of natural habitats and water abstraction were (and still are) the major anthropogenic pressures leading to the extirpation of populations and disjunctive distribution of the remaining ones (e.g. Koutrakis et al., 2007; Perdikaris, 2009; Aquiloni et al., 2010). These diversity losses are expected to develop further in the future, due to spatial expansion and competitive advantages (environmental tolerance, flexible feeding habits, high fecundity, shorter incubation period, rapid growth and aggression) of the nine established non-indigenous crayfish species (NICS) [i.e. the 'old' NICS (introduced since mid-19th century up to 1975 to supplement crayfish stocks and for aquaculture): spiny-cheek crayfish Orconectes limosus (Rafinesque, 1817), signal 
crayfish Pacifastacus leniusculus (Dana, 1852), red swamp crayfish Procambarus clarkii (Girard, 1852), and the 'new' NICS (introduced since 1980 mainly through the aquarium trade and for aquaculture): calico crayfish Orconectes immunis (Hagen, 1870), virile crayfish Orconectes virilis (Hagen, 1870), Kentucky river crayfish Orconectes juvenilis (Hagen, 1870), marbled crayfish or marmorkrebs Procambarus fallax f. virginalis (asexual form of slough crayfish Procambarus fallax), White river crayfish Procambarus acutus (Girard, 1852), yabby Cherax destructor Clark, 1936 (Holdich et al., 2009)]. Moreover, the practically uncontrolled globalized aquarium trade (regular and internet-based) of live ornamental freshwater crayfish possesses additional threat to ICS (e.g., 123 non-indigenous species are available including 107 species of high 'plague' risk originating from North and Central America in the German pet stores; Chucholl, 2010) and public education concerning the risks of releases to the natural environment are practically absent (Holdich et al., 2009). It was projected that if no actions were taken under the current level of NICS expansion, few critically endangered populations of ICS will survive in limited confined areas in 100 years time (Taugbøl and Skurdal, 1999). Therefore, economic incentives and human-generated impacts appear to determine significantly the future status of ICS in a Pan-European level.

As NICS represent a direct threat (not only via the endangerment of ICS) to biodiversity of European freshwater habitats, which are in general already disturbed (Füreder, 2006), the present work aims to examine possible relations and trends between NICS in the EU area and the ultimate anthropogenic factors which are the characteristics of social organization that lead to human exploitation of natural resources and environmental decline and to discuss relevant frameworks to restore/balance the observed metabolic rifts. These factors are demographic (human population density), economic (level of urbanization, gross domestic product (GDP) per capita) and ecological status (footprint/biocapacity) of each country.

\section{MATERIALS AND METHODS}

Data on the number of NICS present in 26 EU countries (excluding Malta which has no crayfish) were supplied by Holdich et al. (2009). All data relevant to population density (persons $\mathrm{km}^{-2}$ ), percentage of urbanization and GDP per capita came from the World Bank (2010). Finally, biocapacity and ecological footprint data were supplied by World Wide Fund (2008). The dependent variable (the number of NICS) was plotted against each one of the above independent variables and coefficient $r$ was calculated for each case.

\section{RESULTS AND DISCUSSION}

\section{> DEMOGRAPHIC EFFECTS ON THE NUMBER OF NICS}

Population density correlates well $(r=0.66)$ with the number of NICS (Figure 1). From the ten crayfish species introduced in European freshwaters, nine have been successfully established due to robustness, fecundity, growth and invasiveness, among others (Holdich et al., 2009), representing a unique success record amongst other animals; most of them are available through aquarium trade as ornamental pets, which are a popular activity in western societies (Perdikaris et al., 2010). Similar studies (Hoffman, 2004; Clausen and York, 2008) suggested that demographic factors are related to environmental degradation as the most densely populated nations have higher rates of threatened species and certainly more hobbyists possessing and culturing crayfish. Our findings demonstrate that human population density is positively correlated to an indirect but a decisive threat to biodiversity represented by the presence of NICS. However, this trend is probably true for the early stages of adaptation and establishment and by no means conclusive, as the subsequent spread and invasion of NICS is not restricted by national barriers. Nevertheless, increased human population pressures in many cases are expected to have an effect on ICS populations (through pollution, water 


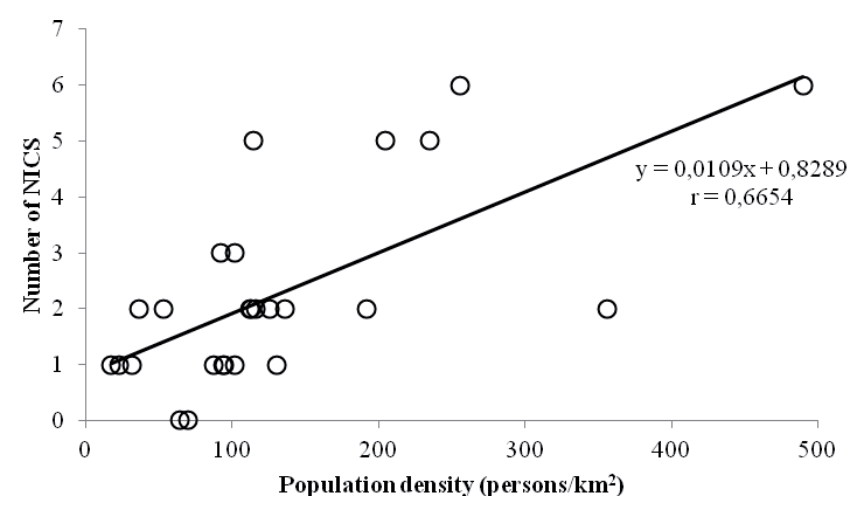

Figure 1

Graphic plot of the number of NICS against population density in the EU countries inhabited by freshwater crayfish (Austria, Belgium, Bulgaria, Cyprus, Czech Republic, Denmark, Estonia, Finland, France, Germany, Greece, Hungary, Ireland, Italy, Spain, Latvia, Lithuania, Luxembourg, Netherlands, Poland, Portugal, Romania, Slovakia, Slovenia, Sweden, United Kingdom).

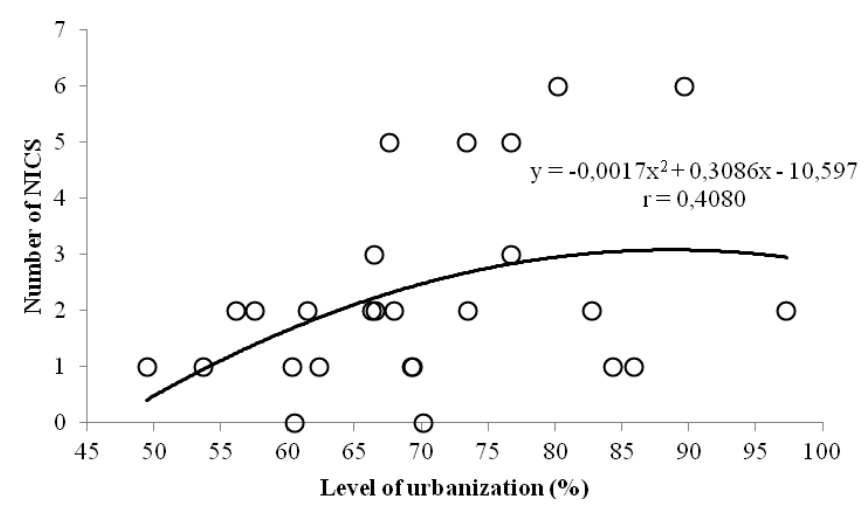

\section{Figure 2}

Graphic plot of the number of NICS against urbanization level in the EU countries inhabited by freshwater crayfish (countries as in Figure 1).

abstraction and loss of wetlands), which probably favour in some extent the spread of the robust alien species which are able to withstand of and flourish in adverse environmental conditions.

\section{> ECONOMIC EFFECTS ON THE NUMBER OF NICS}

Urbanization is regarded as an integral process of modernization and a central theme in the reorganization of world ecology and in nature-society dialectic (Moore, 2000). In fact, the citycountryside antagonism is crucial for the metabolic rift theory mainly on the grounds of natural resources cycling and waste accumulation. However, urbanization level seems to have a moderate effect on the number of NICS presented in EU countries $(r=0.41)$ (Figure 2). It is a fact that cities especially close to airports and ports are the main entrance gates of international trade and also the biggest trading places themselves, however this does not necessarily imply for example that ornamental NICS released deliberately by urban citizens have more chances to survive compared for example to the escapees from a crayfish farm in the countryside, depending primarily on culture density, the number of stocked animals, the number of escapees and finally the species concerned. On the other hand, the case of the marbled crayfish (Martin et al., 2010) represents a major threat arising even from a single specimen released by an urban hobbyist (Feria and Faulkes, 2011). The species has become 


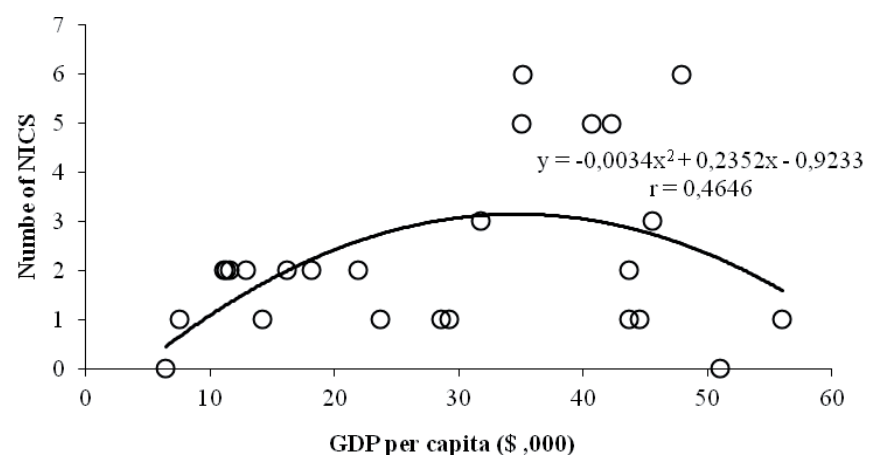

\section{Figure 3}

Graphic plot of the number of NICS against GDP per capita in the EU countries inhabited by freshwater crayfish (countries as in Figure 1 excluding Luxemburg).

widely established in Madagascar; however it was first recorded in 2004 in Netherlands, in small number of sites in Germany and recently in Italy (Holdich et al., 2009).

Capital accumulation has been accused as a major factor for biodiversity destruction (Foster, 1999b). Therefore, tracking any possible relations between economic growth indices and biodiversity or biodiversity risk factors would be valuable to visualise the extent of such an effect on the integrity of the aquatic ecosystems. According to the neo-liberal theories (for review see Clausen and York, 2008), early stages of economic development goes parallel to the environmental degradation but eventually economic improvement (e.g., $>\$ 9000$ measured as GDP per capita; Hoffman, 2004) leads to 'ecological rationalization' and amelioration of the impacts. In the case of NICS, there is a moderate tendency $(r=0.47)$ to gradually increase their numbers in the EU countries up to $\$ 40000$ GDP per capita before they start falling (Figure 3 ). This picture may suggest that economic growth contributes to the amplification of the pressures faced by the ICS in their habitats due to the increased numbers of NICS. Similar outcomes have been reported for the observed and expected decline of endangered species for developed nations (Czech et al. 2000; Naidoo and Adamowicz, 2001) and cross-nationally (Clausen and York, 2008). The absence of NICS in countries with the highest GDP per capita such as Ireland can be explained primarily by its insular isolation. Concerning Bulgaria, the absence of NICS can be attributed to the restricted movement/travelling of people from the Eastern block and to the delayed development of internet-based commerce (i.e. e-shops), which saved this part of Europe from crayfish invasions in the past.

\section{$>$ ECOLOGICAL STATUS AND NICS}

Scientific interest has greatly focused on issues related to the prevention of an irreversible ecological recession due to the increasing demand for energy and resources. Ecological footprinting tools (measuring the human demand of biologically productive land and sea in global hectares required to provide resources and services on waste assimilation) revealed that European per capita ecological footprint during 2005 was about double compared to the available biocapacity ( 4.7 gha.person ${ }^{-1}$ vs. 2.3 gha.person ${ }^{-1}$, respectively) and about 1.7 times higher compared to the global ecological footprint (World Wide Fund, 2008). Therefore, EU countries as a whole overshoot their biological capacity, since the ecological balance is negative, following the global trend of unsustainable resource use and waste accumulation (Kitzes et al., 2008). In this context, there is a moderate trend of increasing number of NICS as we move from the ecological creditor to ecological debtor countries $(r=0.43)$ (Figure 4). This trend could be partly attributed to the introduction of species for replacing already devastated indigenous stocks, aquaculture activities including non-indigenous species and recently the booming of internet-based commerce (i.e. e-shops), mainly in industrialized western European countries with negative ecological balance. All the above activities have been largely depended on foreign inputs and international trade. Overall, the presence of NICS seems to indicate 


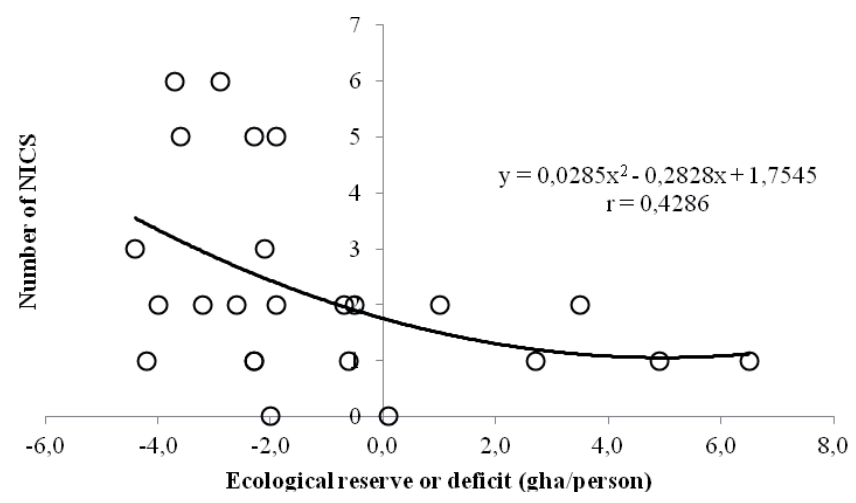

\section{Figure 4}

Graphic plot of the number of NICS against ecological reserve/deficit values in the EU countries inhabited by freshwater crayfish (countries as in Figure 1).

unsustainable practices in resource management and implies possible ecological rifts generated in many sectors of the economic activity.

Managing the spread of NICS is not an easy task given the human-assisted introductions in many European countries (e.g., through aquarium trade, sales of live crayfish for human consumption, use of crayfish as angling baits, escapes form garden ponds especially during floods) (Peay, 2009). It is obvious that profit generation and accordingly strong lobby interests in the aquarium trade are major obstacles against the introduction and enforcement of legal instruments to control the spread of NICS. Moreover, the relative effectiveness of eradication methods (i.e. using chemicals, crayfish 'plague' against susceptible NICS, trapping and biological control by stocking crayfish predators) is dependent on the time of the initial detection of NICS, overall cost and the size of the water body. Accordingly, no simple method effectively eradicating NICS is currently available or is likely to be in the near future (Freeman et al., 2010; Gherardi et al., 2011). Therefore, indirect metabolic rifts are continuously created by the spread of NICS through direct impacts on ICS and other aquatic biota and structural modification of habitats (i.e. consumption of aquatic macrophyte, bank erosion and undermining as well as substrate disturbance) (Nyström et al., 1996), affecting both biodiversity and the integrity of the ecosystems.

Path models for the protection of ICS involving continuous monitoring of both ICS and NICS distribution range, habitat restoration, re-establishment efforts, designation of no-go areas, ark sites and species protection areas (SPAs), prevention of further spread of NICS and 'plague', augmented legislation and better enforcement policies, transboundary co-operation, public education and increased research efforts (see for instance Taugbøl and Skurdal, 1999 and Holdich et al., 2009) have been already proposed. Protection frameworks such as the 92/43/EEC Directive for the protection of fauna and flora and their habitats, the Natura 2000, the EU Water Directive (2000/60/EC), the 708/2007 (EC) Directive for the use of alien and locally absent species in aquaculture and recent actions by the EU to adopt strategies against alien species (Gherardi et al., 2011) are expected to particularly benefit ICS populations across Europe, as well as the development of risk screening tools for NICS (e.g. FI-ISK scoring kit by Tricarico et al., 2010). Moreover, there is a need to address the effects of socio-economic factors on ICS and NICS spread, in order to understand the impact of social forces to environmental change. Monitoring such relationships could assist to some extent in predicting future trends, having always in mind that regularities, linearities and predictability are strongly challenged when the aquatic ecosystems are pushed to their limits.

\section{ACKNOWLEDGEMENTS}

This study was partly supported by the grants Nos. CZ.1.05/2.1.00/01.0024 and 047/2010/Z. 


\section{REFERENCES}

Alderman D.J., 1996. Geographical spread of bacterial and fungal diseases of crustaceans. Rev. Sci. Tech. OIE, 15, 603-632.

Aquiloni L., Tricarino E. and Gherardi F., 2010. Crayfish in Italy: distribution, threats and management. Int. Aquat. Res., 2, 1-14.

Chucholl C., 2010. Invaders for sale: Does the ornamental freshwater crayfish trade constitute an actual and overlooked risk? Proceedings of the Congress 'European Crayfish: Food, Flagships and Ecosystem Services', Poitiers, France, 108 p.

Clausen R. and Clark B., 2005. The Metabolic rift and marine ecology. An analysis of the ocean crisis within capitalist production. Organ. Environ., 18, 422-444.

Clausen R. and York R., 2008. Global biodiversity decline of marine and freshwater fish: A cross-national analysis of economic, demographic and ecological influences. Soc. Sci. Res., 37, 1310-1320.

Czech B., Krausman P. and Devers P., 2000. Economic associations among causes of species endangerment in the United States. BioScience, 50, 593-601.

Diéguez-Uribeondo L., 2006. Pathogens, parasites and ectocommensals. In: Souty-Grosset C., Holdich D.M., Noël P.Y., Reynolds J.D. and Haffner P. (eds.), Atlas of Crayfish in Europe, Muséum National d'Histoire Naturelle, Paris, Patrimoines Naturels, 64, 133-149.

Feria T.P. and Faulkes Z., 2011. Forecasting the distribution of Marmorkrebs, a parthenogenetic crayfish with high invasive potential, in Madagascar, Europe, and North America. Aquat. Invas., 6, 55-67.

Foster J.B., 2000. Marx's ecology: Materialism and nature, Monthly Review Press, New York, 288 p.

Foster J.B., 1999a. Marx's theory of metabolic rift: classical foundations for environmental sociology. Am. J. Sociol., 105, 366-405.

Foster J.B., 1999b. The vulnerable planet: A short economic history of the environment 2nd edition, Monthly Review Press, New York, 160 p.

Freeman M.A., Turnbull J.F., Yeomans W.E. and Bean C.W., 2010. Prospects for management strategies of invasive crayfish populations with an emphasis on biological control. Aquat. Conserv., 20, 211-223.

Füreder L., 2006. Indigenous crayfish habitat and threats. In: Souty-Grosset C., Holdich D.M., Noël P.Y., Reynolds J.D. and Haffner P. (eds.), Atlas of Crayfish in Europe, Muséum National d'Histoire Naturelle, Paris, Patrimoines Naturels, 64, 26-37.

Gherardi F., 2011. Towards a sustainable human use of freshwater crayfish (Crustacea, Decapoda, Astacidea). Knowl. Managt. Aquatic Ecosyst., 401, doi: 10.1051/kmae/2011038.

Gherardi F., Aquiloni L., Diéguez-Uribeondo L. and Tricarino E., 2011. Managing invasive crayfish: is there a hope? Aquat. Sci., 73, 185-200.

Hoffman J., 2004. Social and environmental influences on endangered species: a cross-national study. Sociol. Perspect., 47, 79-107.

Holdich D.M., Reynolds J.D., Souty-Grosset C. and Sibley P.J., 2009. A review of the ever increasing threat to European crayfish from non-indigenous crayfish species. Knowl. Managt. Aquatic Ecosyst., 394-395, doi: 10.1051/kmae/2009025.

Kitzes J., Wackernagel M., Loh J., Peller A., Goldfinger S., Cheng D. and Tea K., 2008. Shrink and share: humanity's present and future Ecological Footprint. Philos. Trans. R. Soc. B, 363, 467-475.

Kottelat M. and Freyhof J., 2007. Handbook of European Freshwater Fishes, Kottelat, Cornol, Switzerland and Freyhof, Berlin,Germany, $646 \mathrm{p}$.

Koutrakis E., Perdikaris C., Machino Y., Savvidis G. and Margaris N., 2007. Distribution, recent mortalities and conservation measures of crayfish in Hellenic fresh waters. Bull. Fr. Pêche Piscic., 385, 25-44.

Koutrakis E., Machino Y., Mylona D. and Perdikaris C., 2009. Crayfish terminology in ancient Greek, Latin and related languages. Crustaceana, 82, 1535-1546.

Longo S.B., 2010. Mediterranean rift: Socio-ecological transformations in the Sicilian bluefin tuna fishery. Crit. Sociol., doi: 10.1177/0896920510382930.

Martin P., Dorn N.J., Kawai T., van der Heiden C. and Scholtz G., 2010. The enigmatic Marmorkrebs (marbled crayfish) is the parthenogenetic form of Procambarus fallax (Hagen, 1870). Contrib. Zool., 79, 107-118.

Moore J.W., 2000. Environmental crises and the metabolic rift in world-historical perspective. Organ. Environ., 13, 123-157.

Naidoo R. and Adamowicz W., 2001. Effects of economic prosperity on numbers of threatened species. Conserv. Biol., 15, 1021-1029.

Nyström P., Brönmark C. and Granéli W., 1996. Patterns in benthic food webs: a role for omnivorous crayfish? Freshw. Biol., 36, 631-646.

Peay S., 2009. Invasive non-indigenous crayfish species in Europe: Recommendations on managing them. Knowl. Managt. Aquatic Ecosyst., 394-395, doi: 10.1051/kmae/2010009.

Perdikaris C., 2009. Biology and distribution of the crayfish species populations in the Hellenic freshwaters, Ph.D. Thesis, Department of Environmental Science, University of the Aegean (in Greek), 217 p. 
Perdikaris C. and Paschos I., 2011. Aquaculture and fisheries crisis within the global crisis. Interciencia, 36, 76-80.

Perdikaris C., Paschos I. and Athanasopoulou E., 2010. Non-indigenous freshwater crayfish species in Greece and risks for biodiversity, World Aquatic Veterinary Medicine Association (WAVMA) Conference: 'Integrated Disease Diagnosis, Control and Treatments in Aquatic Veterinary Medicine - from koi, to cod, to sushi', Athens, Greece. http://conference2010.wavma.org/media/ Presentation\%20PDFs/Wed\%209.00\%20Perdikaris\%20Crayfish\%20Biodiversiry.pdf (accessed 26 April 2011).

Swahn J.Ö., 2004. The cultural history of crayfish. Bull. Fr. Pêche Piscic., 372-373, 243-251.

Taugbøl T. and Skurdal J., 1999. The future of crayfish in Europe: How to make the best of a bad situation? In: Gherardi F. and Holdich D.M. (eds.), Crayfish in Europe as alien species - how to make the best of a bad situation? A.A. Balkema, Rotterdam, 271-279.

Tricarico E., Vilizzi L., Gherardi F. and Copp G.H., 2010. Calibration of FI-ISK, an invasiveness screening tool for non-native freshwater invertebrates. Risk Anal., 30, 285-292.

World Bank, 2010. World development indicators 2010, http://data.worldbank.org/data-catalog/worlddevelopment-indicators (accessed 7 January 2011).

World Wide Fund, 2008. Living planet report, World Wide Fund for Nature, Gland, Switzerland, http://assets.panda.org/downloads/living_planet_report_2008.pdf (accessed 7 January 2011). 